\title{
EJSBS
}

The European Journal of Social \&

Behavioural Science

ISSN: 2301.2218 (ONLINE)
OPENACCESS

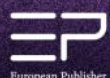

The European Journal of Social and Behavioural Sciences

EJSBS Volume XXX, Issue II (eISSN: 2301-2218)

\section{SEVASTOPOL IN THE HISTORICAL MEMORY OF THE GREAT PATRIOTIC WAR: MEDIA SPACE ANALYSIS}

\author{
Olga Yarmak ${ }^{\mathrm{a} *}$, Mariya Bolshakova ${ }^{\mathrm{b}}$, Anastasiya Maranchak ${ }^{\mathrm{c}}$, \\ Zoya Savina $^{\mathrm{d}}$ \\ ${ }^{a}$ Sevastopol State University, 33 Universitetskaya St., 299053 Sevastopol, Russia \\ ${ }^{b}$ Sevastopol State University, 33 Universitetskaya St., 299053 Sevastopol, Russia \\ c Sevastopol State University, 33 Universitetskaya St., 299053 Sevastopol, Russia \\ ${ }^{d}$ Sevastopol State University, 33 Universitetskaya St., 299053 Sevastopol, Russia
}

\begin{abstract}
This article identifies the content and structural features of social and media communication of Runet users in relation to the information presence of Sevastopol in the construction of the historical memory of the Great Patriotic War. An interdisciplinary approach is used to fully implement the goal and objectives of the research being conducted. Media and information spaces cybermetry intrinsic to modern sociology make it possible to identify new trends in the formation of unconventional historical attitudes about the Great Victory, including the presence of Sevastopol in the historical memory of the Great Patriotic War. The use of the social media monitoring system "Medialogia" enabled an analysis of information flows about the Great Patriotic War and the role of Sevastopol in the Great Victory. The results of the study can contribute to the development of a guide aimed at intensifying the activities in the field of formation of the historical memory of the Great Victory. The authors believe that it will positively affect the consistent upholding of Russia's historical victories and their preservation in the modern digital space by shaping the agenda and managing information flows in the context of the ideological confrontation of the main world actors.
\end{abstract}

Keywords: Heroes, Internet space, big data, cybermetry, the Great Patriotic War, Sevastopol

(C) 2021 Published by European Publisher. www.europeanpublisher.com

${ }^{*}$ Corresponding author. Tel.: +7-978-059-78-38.

E-mail address: olga_yarmak@inbox.ru

doi: $10.15405 /$ ejsbs.294

This work is licensed under a Creative Commons Attribution-NonCommercial-NoDerivatives 4.0 International License. 
https://doi.org/10.15405/ejsbs.294

eISSN: 2301-2218 / Corresponding Author: Olga Yarmak

Selection \& Peer-review under responsibility of the Editors

\section{Introduction}

Sevastopol is currently going through a new historical and geopolitical stage. Taking into consideration its historical significance in the internal political map of Russia and its geopolitical role in the international space, it is necessary to understand that the processes of information influence in the region not only remain significant, but have also become relevant when it comes to studying the factors of formation and functioning of certain information flows. These relate to key ideological meanings of Russia, determining actors and the degree of their influence on the change in the structural components of these ideological constructions.

The novelty of the research lies in the identification of the information infrastructure of semantic structures that form the significance of the role of Sevastopol in the historical memory of the Great Patriotic War by analyzing the information flows of Runet using big data.

The fundamental scientific task of this study is the intellectual search for markers of unconventional semantic activity in Internet content. The theoretical significance of the study lies in the systematic application of cybermetry methods and tools to study the nature, causes, basic structural and other characteristics of unconventional processes of constructing new meanings and destroying fundamental historical semantic structures, in particular related to the meanings of the Great Victory. In turn, the selected system of markers for the mobilization of unconventional construction in Internet content can be used by the expert community for modeling and forecasting information processes, as well as in studies devoted to the analysis of the media and Internet space in the field of the information presence of Sevastopol in the construction of the historical memory of the Great Patriotic War.

The scientific novelty of this study consists in the development of a hybrid research strategy and approbation of the methodology for analyzing information flows in the digital environment, identifying a system of markers of unconventional activity in Internet content, destroying the historical basic attitudes towards the Great Victory and the role of Sevastopol in it. It will help to differentiate information streams, their discourses, and reveal the roles in the partner online communities.

\section{Purpose of the Study}

The main goal of the research is to identify the content and structural features of social and media communication of Runet users in relation to the information presence of Sevastopol in the construction of the historical memory of the Great Patriotic War. Sevastopol is one of the world's ideological outposts of Russia, which makes it necessary to study data on the nature and specifics of the information flows formation and structuring in the region, primarily in 
https://doi.org/10.15405/ejsbs.294

eISSN: 2301-2218 / Corresponding Author: Olga Yarmak

Selection \& Peer-review under responsibility of the Editors

relation to such fundamental semantic foundations as the Great Victory and the Great Patriotic War.

\section{Research Methods}

An interdisciplinary approach is used to fully implement the goal and objectives of the research being conducted. The ideas of cybermetry of media and information spaces, intrinsic to modern sociological science, make it possible to identify new trends in the formation of unconventional historical attitudes about the Great Victory, including the presence of Sevastopol in the historical memory of the Great Patriotic War.

The theoretical foundation of the research is underpinned by a number of inter-related theories such as the discourse theory (Laclau \& Mouffe,1985; Teun, 1998), the collective representations theory (Durkheim, 1995; Le Bon, 1995; Marcuse, 1994), agenda theory (Lippmann, 2004), the concept of socio-political destabilization factors (Goldstone, 1991; Howard \& Parks, 2012), the tradition of realism in the analysis of the nation and interethnic relations (Altermatt, 2000); the theory and concepts of social, ethnic and interethnic attitudes (Uznadze, 2001; Drobizheva, 2008); concepts and theories of the system of identities and ethnic identity (Berger \& Lukman, 1995; Erickson, 1996; Mead, 1925); and the concept of integration and consolidation of society (Zaslavskaya, 2002; Zdravomyslov \& Yadov, 1965).

Social phenomenology principles (Berger \& Lukman, 1995) are used which contribute to the study of the Internet communication factor impact on the image formation of Sevastopol and determination of its role in the Great Patriotic War and cognitive analysis which focuses on the study of the formation processes of the subjective interethnic and interreligious world, subjective perception and interpretation of messages broadcast in social media (Dalton, 1977; Shestopal, 2019).

The works by Castells (2009) are the most significant here. He studies the transition of society into the information age, which he claims, is due to the active development of information and communication technologies. One of the main features of this transition is the development of networks connecting people, institutions and states. McLuhan's (2007) ideas about the specifics of communication in cyberspace, including political, are important for in this study in terms of analyzing Internet content on Russian and anti-Russian topics.

Several Russian scientists have analyzed the impact of information flows on the consciousness and behavior of users. Studies by Bronnikov, Bubnov, Volodenkov, Gradoselskaya, Zverev, Nesterchuk, Solovieva, Ushkin, Howard, Chumikov, Churashova and others regard the Internet as a space for social protest (as cited in Gradoselskaya, 2004). Grachev, Castells, Kwak, Cohen, Lee, Miroshnichenko, Mikhailova, Pavlyutenkova, 
https://doi.org/10.15405/ejsbs.294

eISSN: 2301-2218 / Corresponding Author: Olga Yarmak

Selection \& Peer-review under responsibility of the Editors

Smorgunov, Chevik, Chizhov, Schmidt, Sherstobitov and others are engaged in researching the networking of political actors (as cited in Smorgunov, 2014).

Cases of influence models in social networks (Gubanov et al., 2021), modeling the dissemination of information in social networks (Borgatti \& Everett, 2021; Kuikka, 2018; Wang et al., 2020) are of particular research interest. These interdisciplinary studies present a new approach to using dynamic modeling to analyze communication and dissemination of information in social networks which changes the paradigm of modeling information dissemination in social media and lays out a theoretical basis for solving problems of spacetime modeling in the era of big data allowing researchers to classify information streams and search for communities (clusters) of online users.

\subsection{Empirical research model}

The empirical research model consists of the following methods for collecting and analyzing information:

- content analysis of the texts of Russian Internet media: the analysis of the texts of Russian Internet resources focused on historical topics, discourse about the Great Victory, Sevastopol in the Great Patriotic War for the period 2018-2020;

- discourse analysis of messages from social media users: about 11000 messages from social media users relevant to the research topic; development on the basis of dictionaries of digital markers of message types for automated downloading of an array of big data;

- cybermetry of spontaneous and purposeful information flows in social media: data arrays of automated downloading of Internet content - at least 1 million messages from VKontakte and Facebook users for the period 2018-2020. The method allows for segmenting information flows, identifying their structural, content and dynamic characteristics. Due to the need to obtain a result of high accuracy in determining the sentiment of documents, as well as the lack of the possibility of clustering them according to a specific criterion, typology and assignment of sentiment is done manually.

Working with the service and generating keywords for groups is iterative. After each classification carried out by means of the developed product, a part of the selected documents would be manually scanned in order to find messages that are not distributed correctly. When such messages are found, the search criteria are refined and a new cycle of work with content is launched.

Data for research analysis was obtained by downloading from 'Medialogia', the automatic system for monitoring and analyzing media and social networks in the online mode, using search queries reflecting the situation in the all-Russian and regional social media space 
https://doi.org/10.15405/ejsbs.294

eISSN: 2301-2218 / Corresponding Author: Olga Yarmak

Selection \& Peer-review under responsibility of the Editors

for the topic under study. This automatic system was used for monitoring and analyzing social media because it provides data in real time, being one of the leaders in monitoring and analyzing media and Internet space.

The authors analyzed the information field of Sevastopol, associated with the theme of the Great Patriotic War and given by the regional media, in the period from 2018 to 2020 , based on the results of which 109 newsworthy events were identified. Examples of these ranked by importance and the number of audience reached are shown in Table 1.

Table 1. Newsworthy events related to the topic of Sevastopol in the context of the Great Patriotic War

\begin{tabular}{lll}
\hline Newsworthy events & Source & Views \\
\hline $\begin{array}{l}\text { Buildings in Sevastopol that survived two defenses } \\
\text { (photo) }\end{array}$ & RuInformer & 17297 \\
How Sevastopol became the white-stone pearl of Russia & RuInformer & 17122 \\
"... Why did Hitler still take Sevastopol? ..." & RuInformer & 16828 \\
Sevastopol celebrated the 75th anniversary of the Victory & Iz.RU & 14190 \\
Is heroism "out of trend" in Sevastopol today? & RuInformer & 13698 \\
$\begin{array}{l}\text { Veterans of Sevastopol will receive an additional } \\
\text { payment by Victory Day }\end{array}$ & RG.ru & 11805 \\
$\begin{array}{l}\text { No one is forgotten: "Mom, you cannot imagine what the } \\
\text { Nazis turned Sevastopol into" }\end{array}$ & KP.RU & 10258 \\
\hline
\end{tabular}

The identified news hooks are classified according to thematic criteria and divided into four generalized streams:

1. Stream associated with the general theme of the Victory of the USSR in the Great Patriotic War.

2. Stream associated with social support for veterans of the Great Patriotic War.

3. Stream associated with the battle and the liberation of Sevastopol.

4. Stream associated with the memory of the defense and liberation of Sevastopol, and the restoration of the city after the war.

For each stream, a linguistic model was developed and search queries were formed, allowing using the 'Medialogia' digital markers to identify the necessary data and exclude irrelevant (so-called 'information garbage').

An example of this is the query "Sevastopol AND (Great Patriotic War OR WWII) AND fascism AND NOT victory". In this case, the task was to analyze publications whose purpose is to distort the events of the Great Patriotic War through the exaltation of fascism. Receiving this request, the Medialogia system searches for messages containing the words 
https://doi.org/10.15405/ejsbs.294

eISSN: 2301-2218 / Corresponding Author: Olga Yarmak

Selection \& Peer-review under responsibility of the Editors

Sevastopol, Great Patriotic War (or its abbreviated form) and fascism, and excluding the word "victory", which is extremely rare in official publications, due to the fact that historically and connotatively, the concepts of 'Great Patriotic War' and 'victory' are inextricably linked.

The use of 'Medialogia' for monitoring social media made it possible to accumulate and structure information documents (messages, comments) from social networks, forums, blogs, instant messengers and to determine such parameters of information flows as the weight of the information flow, its dynamics, socio-demographic characteristics of the authors stream, their geolocation, and the sentiment of Internet content. The data obtained can be interpreted as 'big sociological data' that allow the analysis of the interaction of individuals with information and their behavior on the Internet. It makes it possible to talk about the formation of a new methodological paradigm of social sciences on a theoretical and methodological basis, according to which an individual's reality does not correspond to the ideal orderliness, but is built into information and communication networks.

Thus, this study is based on a mixed-method design where the quantitative aspect related to cybermetry of spontaneous information flows in social media and targeted information flows in social media, and the analysis of social network graphs while the qualitative related to the discourse analysis of social media messages and content analysis of Russian texts in internet media. Quantitative methods are aimed at obtaining empirical data on the structural and content characteristics of information flows while the qualitative ones are focused on the study of their subjective values and meanings presented in these flows.

\section{Findings and Discussion}

Based on the content downloaded from Medialogia, the information flow related to the battle and liberation of Sevastopol for the period from January 9, 2020 to December 24, 2020 was analyzed. The following words and phrases were used as filters to download the appropriate content; 'Sevastopol', 'The Great Patriotic War', 'Victory Parade', 'Victory Day', 'Immortal Regiment', 'Memory', and 'Heroes'. This resulted in 11270 messages downloaded from the social networks VKontakte, Facebook, Odnoklassniki, and YouTube. When analyzing the sentiment of messages, the presence of expressive expressions, value judgments, the opinion of the authors in relation to the topic, as well as the opinions expressed in the comments, when the author's position prevails over the others, were taken into account. The quantitative analysis of the message sentiment revealed a ratio of 844 positive messages, 555 negative messages and 9871 neutral messages. Figure 1 displays the analysis in percentages. 


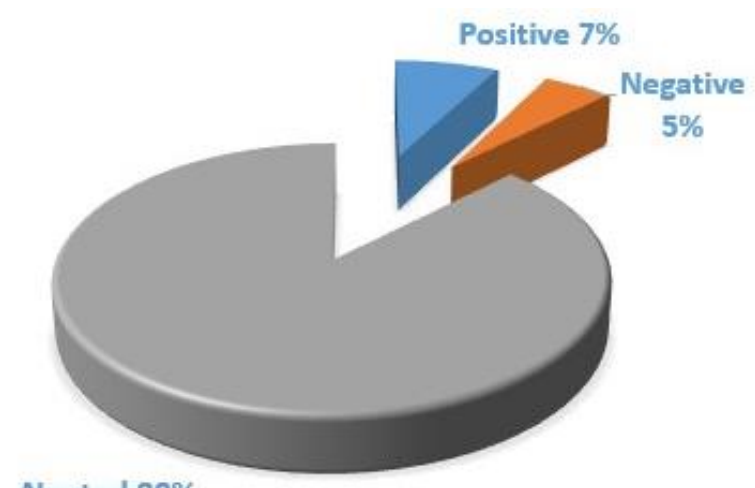

Neutral $88 \%$

Figure 1. The Message Sentiment (in percentage)

The maximum number of positive messages (234) fell on Marine Corps Day on November 27, 2020. The response to this news hook shows the heightened involvement of society in events related to military holidays. This proves the importance of such values as patriotism, memory of exploits, valor and honor of the military and those who consider themselves to be the Marine Corps.

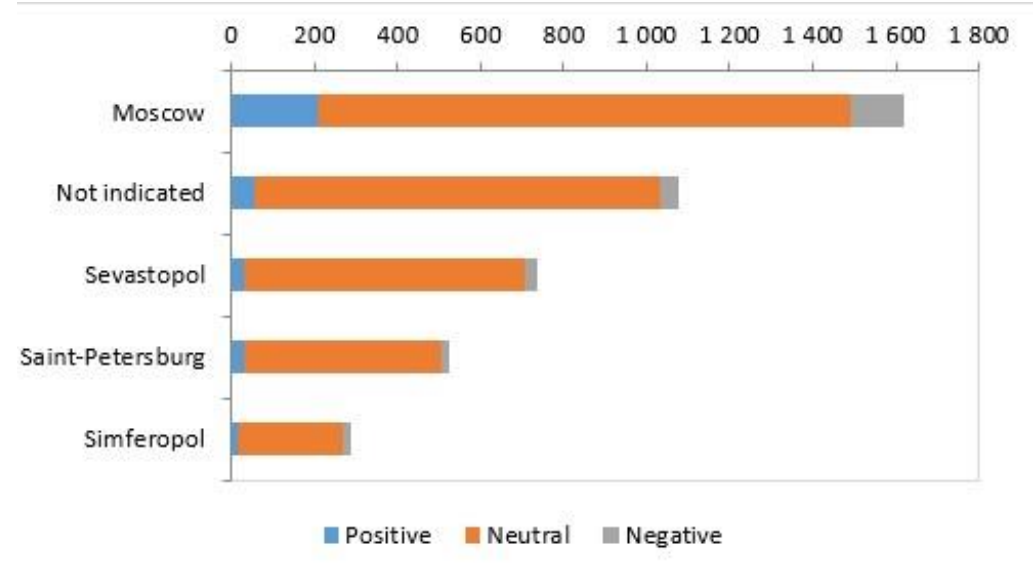

Figure 2. Top 5 Russian Cities Involved

The top 5 Russian cities involved is shown on Figure 2. The greater number of reports in Moscow is explained by the high concentration of federal publications in the capital of Russia. The "not indicated" category most likely reflects publications that do not have an official geolocation.

The gender is indicated by $41 \%$ of authors. The ratio by gender revealed $47 \%$ were female and 53\% were male. Hence, it can be assumed that the slightly higher involvement of 
the males can be explained by the traditional interest of men in military and political topics.

Figure 3 displays the gender ratio.

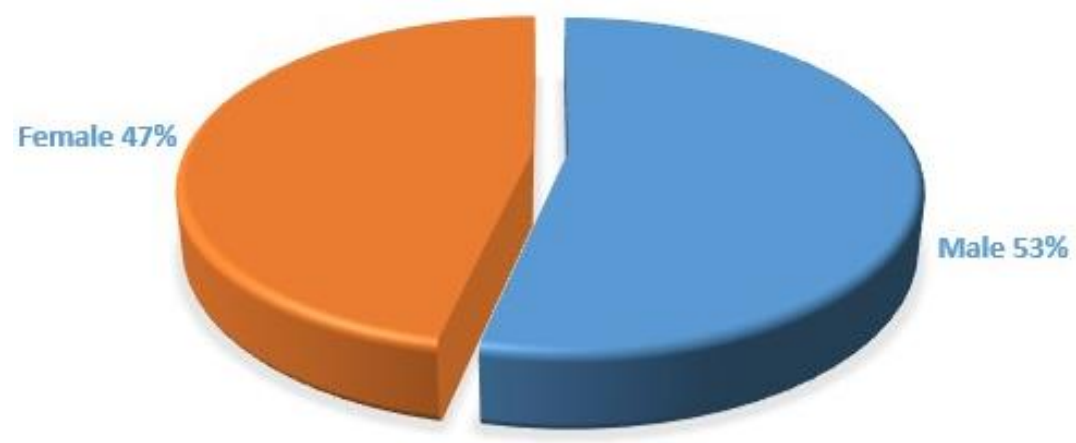

Figure 3. Gender Ratio of the Audience (in percentage)

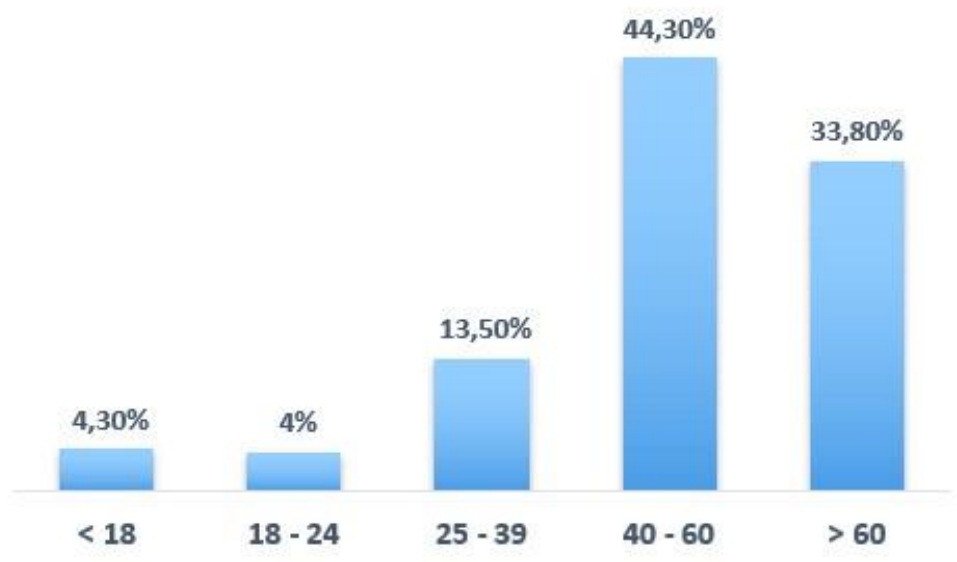

Figure 4. The Authors`Age

The majority of the authors (78\%) interested in the topic under study were mature adults between 40-60 years old (44\%) and over 60 years old (34\%). It is understandable that this age group would be more interested in issues of war, history and politics; considering historical periods as one of the main value-semantic milestones in Russian history, honoring memory and taking care of the historical heritage, heroes, supporting the importance of military victories and the history of the country. Audiences under the age of 25 would not show such interest in these topics as they are more interested in current economic issues. In fact, the analysis of messages revealed that this category opposed the holding of the Victory Parade in favor of investing funds in measures for the improvement and economic development in general. They believed that the money allocated for the parades could be invested in financial 
https://doi.org/10.15405/ejsbs.294

eISSN: 2301-2218 / Corresponding Author: Olga Yarmak

Selection \& Peer-review under responsibility of the Editors

support for veterans. In this way, in their opinion, the historical memory and exploits of veterans and heroes of the Great Patriotic War would be honored.

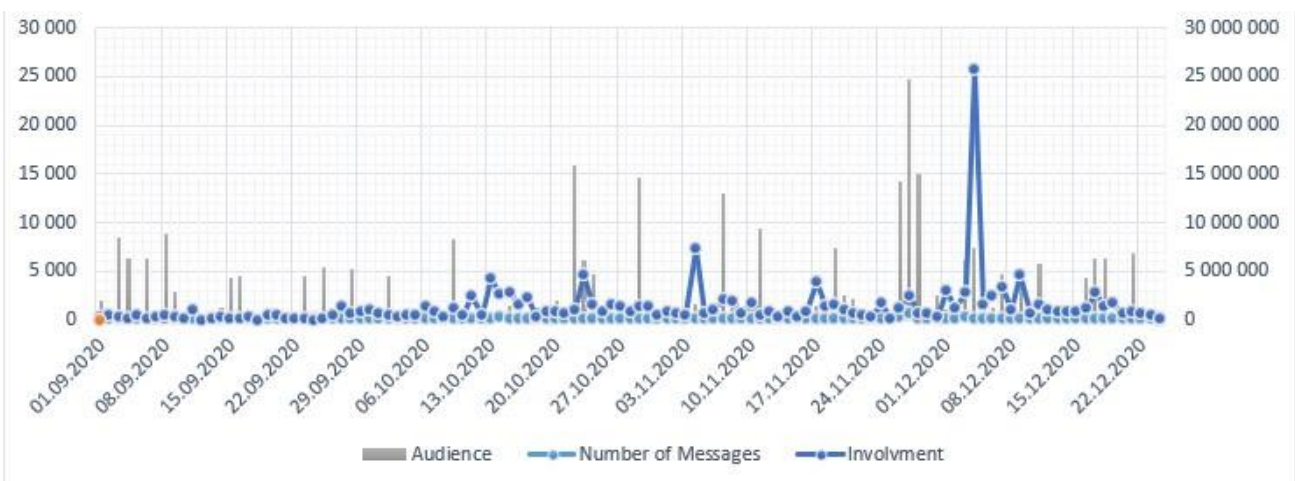

Figure 5. Dynamics of Messages

Heightened involvement was observed in the information flow on April 12, 2020 - on the birthday of the writer Lagin Lazarev, who worked for the newspaper Krasny Chernomorets of the Black Sea Fleet during the Great Patriotic War and who participated in the defense of Odessa, Sevastopol, Kerch, and Novorossiysk, which underscores the popularity and importance of heroes of Victory.

In the same period, blogger Dmitry Puchkov (Goblin) (the audience for the author's channel is 2,070,000 users) presented the video 'The Russian North - a history of conquest: Alaska and icebreakers, the atomic power of the Union' (https://www.youtube.com/watch? $\mathrm{v}$ $=$ zOTIA93I3Kc) with 394,617 views. Content analysis of the comments under this video revealed a high positive response from the audience demonstrating an interest in history and patriotism, and a desire to promote this topic on the network.

\section{Conclusion and Implications}

Media-analytical research has revealed the following agendas. First of all, the analysis of information flows showed that today, the information space in relation to the phenomenon of the Great Patriotic War is heterogeneous. First of all, this is expressed in the heterogeneity of the audience according to age where people of different age categories have different attitudes not only to the war itself, but to its representation in the modern media space. This issue is related to the understanding the perceptions of different age groups to how exactly historical memory should be honoured - to finance and organize specific thematic events or to direct resources to provide direct assistance to the heroes of the war. The next agenda concerns 
https://doi.org/10.15405/ejsbs.294

eISSN: 2301-2218 / Corresponding Author: Olga Yarmak

Selection \& Peer-review under responsibility of the Editors

the heroes of the war as living historical artefacts. The categories 'war veteran' and 'children of war' are directly related to the war and to the memory of the Great Victory and military events. It can be assumed that when they pass away, the attitude to the Great Patriotic War may change and/or will fade to a distant memory in the minds of people; although, results can still be observed in the geopolitical, urban spheres in Russia as a whole, and in Sevastopol. The role of Sevastopol and its influence on the course of military events, and hence, its importance as a patriotic capital and base of the Black Sea Fleet is recognized by people of different age groups, which expresses its importance in maintaining patriotism. Awareness of one's strength and the memory of a common history can have a beneficial effect on the social capital of a society. Therefore, it can be assumed that it is necessary to prevent tendencies that may diminish or eliminate the importance of military events related to the Great Victory, which could negatively affect the climate of Russian society.

The results of the study can contribute to the development of a guide for strengthening activities in the field of formation of a permanent historical memory of the Great Victory and the role of Sevastopol in the historical memory of the Great Patriotic War among Russians. This will positively affect the consistent upholding of Russia's historical victories and their preservation in the modern digital space by shaping the agenda and managing information flows in the context of the ideological confrontation of the main world actors.

\section{Acknowledgements}

The author(s) declare that there is no conflict of interest.

The research was funded by RFBR and the government of Sevastopol, project number 20-411-920004 "Sevastopol in Historical Memory of the Great Patriotic War: Analysis of Runet Information Flows Using Big Data".

\section{References}

Altermatt, W. (2000). Etnonatsionalizm v Yevrope [Ethno-nationalism in Europe]. RSSU. Berger P., \& Luckman, T. (1995). Social construction of reality. Penguin Books Borgatti, S. P., \& Everett, M. G. (2006). A Graph-theoretic perspective on Centrality. Social Networks, 28, 466-484. https://doi.org/10.1016/j.socnet.2005.11.005

Castells, M. (2009). The Rise of the Network Society, The Information Age: Economy, Society and Culture (Vols. 1 - 3). Blackwell.

Dalton, R. G. (1977). Economic Anthropology. American Behavioral Scientist, 20, 635-656. https://doi.org/10.1177/000276427702000504

Drobizheva, L. M. (2008). Natsional'no-grazhdanskaya i etnicheskaya identichnost': problemy pozitivnoy sovmestimosti [National, civic and ethnic identity: problems of positive compatibility]. https://www.civisbook.ru/files/File/Nacionalno-grajd.pdf 
Durkheim, E. (2006). Sotsiologiya. Yeyo predmet, metod, prednaznacheniye [Sociology. Its subject, method and purpose]. Canon.

Erickson, E. (1996). Identichnost': yunost' i krizis [Identity: adolescence and crisis]. Progress.

Goldstone, J. A. (1991). Revolution and Rebellion in the Early Modern World. University of California Press

Gradoselskaya, G. V. (2004). Setevyye izmereniya v sotsiologii [Network Dimensions in Sociology: A Study Guide]. Novy Uchebnik.

Gubanov, D. A., Novikov, D. A., \& Chkhartishvili, A. G. (2009). Models of Influence In Social Media. https://www.researchgate.net/profile/Dmitry_Novikov5/publication/ 274390365_Modeli_vliania_v_socialnyh_setah/links/55900ad908ae15962d8c3dvlian/ Modelidf

Howard, P. N., \& Parks, M. R. (2012). Social Media and Political Change: Capacity, Constraint and Consequence, Journal of Communication, 62, 359-362. https://doi.org/10.1111/j.1460-2466.2012.01626.x

Kuikka, V. (2018). Influence spreading model used to analyze social networks and detect subcommunities. Comput Soc Netw, 5. https://doi.org/10.1186/s40649-018-0060-z

Laclau, E., \& Mouffe, C. (1985). Hegemony and Socialist Strategy: Towards a Radical Democratic Politics. Verso.

Le Bon, G. (1995). Psikhologiya narodov $i$ mass [Psychology of Peoples and Crowds]. "Maket".

Lippmann, W. (2004). Public opinion. Dover Publications.

Marcuse, H. (1994). Odnomernyy chelovek [One-dimensional person]. REFL-Books.

McLuhan, M. (2007). Ponimanie Media: Vneshniye Rasshireniya Cheloveka [Understanding Media: The Extensions of Man]. Kuchkovo Pole.

Mead, G. H. (1925). Genesis of Self and Social Control. International Journal of Ethics, 35, 251-277.

Shestopal, E. B., Smulkina, N. V., \& Morozikova, I. V. (2019). Sravnitel'nyy analiz obrazov svoyey strany $u$ zhiteley rossiyskikh regionov [Comparative analysis of the images of their country among residents of Russian regions]. Comparative politics, 10(3), 74-94. https://doi.org/10.24411/2221-3279-2019-10031

Smorgunov, L. V., \& Sherstobitov, A. S. (2014). Politicheskiye Seti: Teoriya I Metody Analiza [Political Networks: Theory and Methods of Analysis]. Aspekt-Press.

Teun, V. D. (1998). Ideology: A Multidisciplinary Approach. Sage.

Uznadze, D. N. (2001). Psikhologiya ustanovki [Psychology of attitudes]. Piter.

Wang, H., Wang, F., \& Xu, K. (2020) Modeling Information Diffusion in Online Social Networks with Partial Differential Equations. https://www.springer.com/gp/book/ 9783030388508

Zaslasvskaya, T. I. (2002). Sotsiyetal'naya transformatsiya rossiyskogo obshchestva: Deyatel'nostno-strukturnaya kontseptsiya [Societal Transformation of Russian Society: Activity-Structural Concept, in Russian]. Delo.

Zdravomyslov, A. G., \& Yadov, V. A. (1965). Otnosheniye k trudu i tsennostnyye oriyentatsii lichnosti [Attitude to work and personal value orientations]. Sociology in the USSR. (Vol.2). Mysl. 